\title{
Perhitungan Cooling Capacity Yang Dibutuhkan Pada Kapal Tanker 17500 LTDW
}

\author{
Cooling Capacity Calculations Required On Tanker Ship 17500 LTDW \\ Syeihan Syahrul Syah ${ }^{1}$, Novi Sukma Drastiawati ${ }^{2}$, Helmy Taufan ${ }^{3}$ \\ Jurusan Teknik Mesin Universitas Negeri Surabaya ${ }^{1,2)}$ PT Pal Indonesia (Persero) ${ }^{3)}$ \\ 1syehiansyah@mhs.unesa.ac.id \\ nnovidrastiawati@unesa.ac.id \\ 2helmy.taufan@gmail.com
}

\begin{abstract}
Abstrak- Jurnal ini menjelaskan tentang perhitungan cooling capacity yang dibutuhkan pada Kapal Tanker 17500 LTDW, perhitungan cooling capacity bertujuan untuk mengetahui daya compressor yang dibutuhkan pada system pendingin. Metode yang digunakan adalah menghitung cooling capacity berdasarkan GA (General Arranggement) yang mencakup beberapa parameter yaitu jumlah orang, jumlah jendela, volume ruangan, equipment, dan panas dari lampu. Sehingga didapatkan perhitungan Heat Calculation, Air Capacity, dan Cooling capacity pada sebuah kapal tanker. Hasil penelitian ini menunjukkan bahwa cooling capacity kapal Tanker 17500 LTDW sebesar $487,87 \mathrm{~kW}$.
\end{abstract}

Kata Kunci-Cooling Capacity, Kapal, HVAC, temperatur, kelembaban

\footnotetext{
Abstract - This journal explains the calculation of the cooling capacity needed on a Tanker Ship 17500 LTDW, the calculation of cooling capacity aims to determine the compressor power needed in the cooling system. The method used is calculating cooling capacity based on GA (General Arrangement) which includes several parameters, namely number of people, number of windows, room volume, equipment, and heat from lights. So that the calculation of Heat Calculation, Air Capacity, and Cooling capacity is obtained on a tanker. The results of this study indicate that the tanker 17500 LTDW cooling capacity was $487.87 \mathrm{~kW}$.

Key Words - Cooling Capacity, ship, HVAC, temperature, humidity
}

\section{Pendahuluan}

Dewasa ini kebutuhan pada pengkondisian udara dalam ruangan sangat penting, salah satunya dalam bidang perkapalan. Hal ini disebabkan karena semakin meningkat kebutuhan konsumen pada aspek kenyamanan dan keamanan didalam kapal. Penggunaan system pendingin dalam ruangan termasuk dalam bidang HVAC (heating, ventilation, dan airconditioning). Tujuan penggunaan system HVAC pada ruangan kapal adalah untuk memberikan kenyamanan, menjaga suhu dan kelembaban, dan menjaga komponen instrument dan elektronik pada kapal dalam kondisi terbaik. Untuk mencapai kondisi udara yang diinginkan, diperlukan peralatan dan system pendinginan yang mampu mengatur kondisi udara dalam ruangan sesuai dengan jumlah beban pendinginan.
Beban pendinginan (cooling capacity) sebenarnya adalah jumlah panas yang dipindahkan oleh sistem pengkondisian udara setiap waktu. Beban pendinginan terdiri atas panas yang berasal dari ruang dan tambahan panas. Tambahan panas adalah jumlah panas setiap saat yang masuk kedalam ruang melalui kaca secara radiasi maupun melalui dinding akibat perbedaan temperature, pengaruh penyimpanan energi pada struktur bangunan, serta peralatan - peralatan listrik seperti lampu dan peralatan elektronik lainnya.

Kapal Tanker 17500 LTDW merupakan salah satu produk unggulan PT. PAL INDONESIA. Tahapan awal sebelum proses produksi kapal adalah mendesain kapal. salah satu proses penting dalam mendesain system pendinginan. Jurnal ini menjelaskan tentang merancang sistem pendingin yaitu perhitungan cooling capacity pada HVAC (heating, ventilation, dan air-conditioning) yang dibutuhkan pada kapal tanker 17500 LTDW.

\section{KAJIAN PUSTAKA}

\section{A. Pegertian HVAC}

HVAC merupakan singkatan dari Heating, Ventilation, and Air Conditioning, yang mana sistem pengkondisian udara ini merupakan aplikasi dari beberapa cabang ilmu Mechanical Engineering yaitu termodinamika, mekanika fluida, dan perpindahan panas.

Disebut "sistem" karena terdiri dari beberapa mesin yang masing-masing memiliki fungsi yang berbeda, yang terintegrasi sedemikian rupa sehingga membentuk suatu sistem tata udara yang dapat mengontrol suhu, kelembaban, tekanan udara, tingkat kebersihan, pola aliran udara serta jumlah pergantian udara di ruang produksi sesuai dengan persyaratan ruangan yang telah ditentukan.

Dalam dunia perkapalan HVAC digunakan untuk mendesain sistem pendinginan dan sirkulasi udara dalam setiap ruangan di dalam kapal, sehigga dapat memberikan kenyamanan bagi awak kapal, untuk melindungi kwalitas muatan, untuk ventilasi dan pembebasan gas pada ruang pompa kapal tanker dan sebagainya. HVAC juga berfungsi untuk menjaga suhu ruangan dan sirkulasi udara yang didalamnya terdapat peralatan control atau engine seperti control room, engine room, workshop (Utomo, 2007). 
B. Dasar Perhitungan HVAC di dalam ruangan

\section{Heat Calculation}

Menurut Taufan (2006) Sumber beban panas yang diderita ruangan berasal dari :

a) Beban panas akibat transmisi (rambatan) melewati dinding, plafond dan juga lantai ruangan $\left(Q\right.$ transmisson $\left.=Q_{T r}\right)$

b) Beban panas dari panas penghuni ruangan $(Q$ Person $=Q_{P}$ )

c) Beban panas dari panas rambatan dari jendela $(Q$ Window $=Q_{W}$ )

d) Beban panas dari penggunaan lampu penerangan $\left(Q\right.$ Lamp $\left.=Q_{L}\right)$

e) Beban panas dari peralatan yang digunakan dalam ruangan $\left(Q\right.$ Machine $\left.=Q_{M}\right)$

Sehingga total beban panas yang ditanggung oleh mesin pendingin $\left(\mathrm{Q}_{\mathrm{T}}\right)$ :

Qtotal $=\mathrm{Q}_{\mathrm{Tr}}+\mathrm{Q}_{\mathrm{p}}+\mathrm{Q}_{\mathrm{w}}+\mathrm{Q}_{\mathrm{L}}+\mathrm{Q}_{\mathrm{m}}$

a) Panas rambatan lewat dinding, palfon dan lantai ruangan $\left(Q_{T r}\right)$

Adapun rumus yang digunakan adalah:

$$
\mathrm{Q}_{\mathrm{Tr}}=\mathrm{K} \times \mathrm{A} \times \Delta \mathrm{T} \text { (Watt) }
$$

Keterangan :

$\mathrm{Q}_{T r}=$ Panas keseluruhan ruangan (Watt).

$\mathrm{K}=$ koefisien transfer panas $\left(\mathrm{W} / \mathrm{m}^{2}{ }^{\circ} \mathrm{C}\right)$

$\mathrm{A}=$ Luasan yang dirambati panas $\left(\mathrm{m}^{2}\right)$.

$\Delta \mathrm{T}=$ Perbedaan temperatur antara udara luar dengan temperatur dalam ruangan $\left({ }^{\circ} \mathrm{C}\right)$.

b) Panas Dari Orang (penghuni) $\left(Q_{P}\right)$

TABEL I

PANAS YANG DIHASILKAN MANUSIA

\begin{tabular}{|l|c|c|c|}
\hline \multirow{2}{*}{$\begin{array}{c}\text { Degree of } \\
\text { actifity }\end{array}$} & \multicolumn{3}{|c|}{ Heat rate : BTU/h (Kcal/h) } \\
\cline { 2 - 4 } & Sensible & Latent & Total \\
\hline Dancing & $245(62)$ & $605(153)$ & $350(214)$ \\
\hline Person Eating & $220(55)$ & $330(83)$ & $550(138)$ \\
\hline Waiters & $300(76)$ & $700(176)$ & $1000(252)$ \\
\hline $\begin{array}{l}\text { Mdade } \\
\text { Activity }\end{array}$ & $200(50)$ & $250(63)$ & $450(113)$ \\
\hline $\begin{array}{l}\text { Light Activity } \\
\text { Catatan : } 1 \mathrm{~W}=0.86 \mathrm{Kcal} / \mathrm{h}\end{array}$ & $=3.412 \mathrm{BTU} / \mathrm{h}$ \\
$113 \mathrm{Kcal} / \mathrm{h}$ & $=132 \mathrm{~W}$ \\
$101 \mathrm{Kcal} / \mathrm{h}$ & $=117 \mathrm{~W}$ \\
$138 \mathrm{Kcal} / \mathrm{h}$ & $=160 \mathrm{~W}$
\end{tabular}

Rumus yang digunakan untuk menemukan panas yang dihasikan manusia adalah:

Qp = Heat rate $\times$ Qty Person (Watt)

Keterangan :

Heat rate $=$ Panas manusia

Qty Person $=$ Total manusia c) Panas Rambatan Melalui Jendela (kaca) (QW)

Menurut Taufan (2006) Jumlah panas yang merambat melalui jendela kaca dihitung berdasarkan formula sebagai berikut :

Qw $=\mathrm{K} \times \mathrm{A} \times \Delta \mathrm{T} \times$ Qty (Watt)

Keterangan :

Qw = Jumlah panas yang merambat (Watt)

$\mathrm{A} \quad=$ Luas Jendela (m2)

$\mathrm{K}=$ Koerfisien transfer panas

$=6.5 \mathrm{w} / \mathrm{m} 2{ }^{\circ} \mathrm{C}$ (single glass)

$=3.5 \mathrm{w} / \mathrm{m} 2{ }^{\circ} \mathrm{C}$ (double glass)

$\Delta \mathrm{T}=$ Perbedaan temperatur luar dan dalam ruangan $\left({ }^{\circ} \mathrm{C}\right)$

Bila jendela tersebut langsung kena sinar matahari, maka jumlah panas yang merambat adalah :

$\mathrm{Q}=350 \mathrm{w} / \mathrm{m} 2$ (jendela tanpa interior shading)

$\mathrm{Q}=240 \mathrm{w} / \mathrm{m} 2$ (jendela dilengkapi dengan shading)

d) Panas dari Lampu (QL)

TABEL III

PANAS YANG DI HASILKAN LAMPU

\begin{tabular}{|l|c|c|}
\hline \multirow{2}{*}{\multicolumn{1}{|c|}{ Space }} & \multicolumn{2}{|c|}{ Heat Gain from general lighting } \\
& $\left(\mathbf{w} / \mathbf{m}^{\mathbf{2}}\right)$ \\
\cline { 2 - 3 } & Incandescent & Flourescent \\
\hline Cabin, ect. & 15 & 8 \\
Mess or Dinning & 20 & 10 \\
room. Gymnasium, & 40 & 20 \\
\hline
\end{tabular}

Untuk menemukan panas yang dihasilkan dari lampu rumus yang digunakan adalah:

$$
\mathrm{QL}=\mathrm{K} \times \mathrm{A} \text { (Watt) }
$$

Keterangan :

$\mathrm{K}=$ Panas yang di hasilkan oleh lampu

$\mathrm{A}=$ Luasan Area (p x l) (Floor)

Catatan : Umumnya lampu yang digunakan untuk ruang akomodasi kapal adalah type flourescent (dalam perhitungan bila tidak ada keterangan, maka panas lampu yang diperhitungkan adalah type Flourescent).

e) Panas dari peralatan yang ada dalam ruang $\left(Q_{M}\right)$

Berdasarkan pengalaman, maka besarnya panas yang diakibatkan oleh suatu peralatan dalam suatu ruangan adalah sebagai berikut :

$\begin{array}{lll}\text { Wheel House } & : 1000-2500 & \text { Watt } \\ \text { CIC Room } & : 1000-2500 & \text { Watt } \\ \text { Radio Room } & : 500-2500 & \text { Watt } \\ \text { Mess Room } & : 100-500 & \text { Watt } \\ \text { Engine Control Room } & : 3500-7500 & \text { Watt }\end{array}$

2. Kapasitas Udara

Kapasitas udara adalah jumlah uap air maksimum yang dapat dikandung oleh udara pada suatu temperatur. Sama halnya dengan sirkulasi udara, kapasitas udara dalam kapal juga sangat penting pada ruang kapal. Kapasitas udara dalam kapal berfungsi melindungi peralatan 
elektronik pada kapal yang mengeluarkan beban panas dan sebagai faktor kenyamanan penghuni dalam ruang tersebut.

Menurut Taufan (2006) kapasitas udara yang harus disuplai ke dalam ruang untuk mencapai temperatur dan kelembapan ruang relatif sesuai dengan yang diinginkan dihhitung berdasarkan formula sebagia berikut :

$$
\mathrm{V}=\mathrm{Qr} /(\rho . \mathrm{Cp} . \Delta \mathrm{t})
$$

$\mathrm{V}=$ Kapasitas udara $\left(\mathrm{m}^{3} / \mathrm{h}\right)$

$\mathrm{Qr}=$ Total panas yang diderita ruang $($ watt $)$

$\boldsymbol{\rho}=$ densitas udara $\left(1.2 \mathrm{~kg} / \mathrm{m}^{3}\right)$

$\mathrm{Cp}=$ Panas Spesifik udara $\left(1 \mathrm{KJ} / \mathrm{KG}^{\circ} \mathrm{C}\right)$

$\Delta \mathrm{t}=$ Perbedaan temperatur udara yang masuk ruang dengan temperatur ruang $\left({ }^{\circ} \mathrm{C}\right)$ untuk kenyamanan manusia, maka sebaiknya $\Delta \mathrm{t}$ tidak lebih dari $10^{\circ} \mathrm{C}$.

3. Perhitungan Sirkulasi Udara (Air Changes)

Menurut Taufan (2006) nilai minimal sirkulasi udara untuk ventilasi mekanis telah ditentukan oleh beberapa peraturan antara lain SOLAS, ISO, yang dimaksudkan untuk kenyamanan penghuni ruang yan dikondisikan, jumlah sirkulasi udara tergantung pada beban panas yang diderita ruang dengan formula sebagai berikut :

$$
\mathrm{Lw}=\mathrm{v} / \mathrm{V}
$$

$\mathrm{Lw}=$ Air Change $(\mathrm{x} / \mathrm{h})$

$\mathrm{v}=$ Kapasitas udara yang masuk $/ \operatorname{keluar}\left(\mathrm{m}^{3} / \mathrm{h}\right)$

$\mathrm{V}=$ Volume ruang $\left(\mathrm{m}^{3}\right)$

TABEL IIIII

SIRKULASI UDARA DALAM RUANGAN

\begin{tabular}{|c|l|c|}
\hline No & \multicolumn{1}{|c|}{ Room Conditioned } & $\begin{array}{c}\text { Air Change } \\
(\mathrm{x} / \mathrm{h})\end{array}$ \\
\hline 1. & Living Room / Wheel house & 8 \\
\hline 2. & Public Room / Office & 12 \\
\hline 3. & Praktik & 12 \\
\hline 4. & Chart Room & 12 \\
\hline 5. & Radio Room & 20 \\
\hline 6. & CIC Room & 20 \\
\hline 7. & Galley & 20 \\
\hline 8. & Eng. Control Room & 20 \\
\hline 9. & Cargo Control Room & 20 \\
\hline 10. & Laundry & 15 \\
\hline 11. & Spoot Cooling Room & 6 \\
\hline
\end{tabular}

Catatan : Untuk kesehatan manusia ( agar tidak masuk angin ) maka sebaiknya air change tidak lebih dari 30 $\mathrm{x} / \mathrm{h}$

\section{Perhitungan Enthalphy}

Menurut Taufan (2006) Enthalpy adalah panas atau energi dalam satuan kilo joule yang terdapat dalam $1 \mathrm{~kg}$ udara.

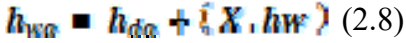

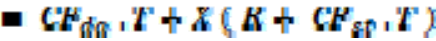

$h_{w a}=$ Enthalpy udara basah $(\mathrm{KJ} / \mathrm{KG})$

$h_{d a}=$ Enthalphy udara kering $=$ sensible heat $(\mathrm{KJ} / \mathrm{KG})$

$h_{w}=$ Enthalphy air = latent heat $(\mathrm{KJ} / \mathrm{KG})$

$X \quad=$ Jumlah air yang terkandung dalam udara

$R=$ Jumlah panas / kalori yang dibutuhkan untuk menguapkan $1 \mathrm{~kg}$ air

$C P_{d a}=$ Panas spesifik udara kering $\left(1 \mathrm{KJ} / \mathrm{KG}^{\circ} \mathrm{C}\right)$

$C P_{s t}=$ Panas spesifik uap air $\left(1.92 \mathrm{KJ} / \mathrm{KG}^{\circ} \mathrm{C}\right)$

$T=$ Temperatur udara yang direncanakan $\left({ }^{\circ} \mathrm{C}\right)$

\section{Psychrometric Diagram}

Psikrometrik adalah bidang yang mempelajari tentang bagaimana menentukan sifat-sifat fisis dan termodinamika suatu gas yang didalamnya terdapat campuran antara gas-uap. Sebagai contoh adalah menentukan sifat-sifat dari campuran udara dan uap air. Adapun sifat-sifat tersebut anatara lain: Dry Bulb Temperature, Wet Bulb Temperature, Dew Point, Relative Humidity, Humidity Ratio, Enthalpy, Volume Spesific. Psikometrik diagram merupakan penggambaran secara grafis untuk beberapa properti penting dari udara lembab (Michael, 2007)

6. Kapasitas Pendinginan (Cooling Capacity)

Menurut Taufan (2006) Kapasitas beban pendinginan diperoleh sesuai formula di bawah ini.

$$
\mathrm{QC}=\mathrm{v} \cdot \rho . \Delta \mathrm{h}
$$

$\mathrm{QC}=$ kapasitas beban pendingin

$\mathrm{v}$ = Kapasitas udara yang akan disuplai ke dalam ruang. $\left(\mathrm{m}^{3} / \mathrm{h}\right)$

$\rho=$ Densitas udara.

$\Delta \mathrm{h}=$ Perbedaan enthalphy antara dua udara yang masuk unit temperatur terendah dalam unit cooler. (Temperatur terendah tercapai saat $\mathrm{RH}$ $\pm 95 \%)$.

\section{METODE}

Metode yang digunakan dalam menentukan beban pendinginan (cooling capacity) pada kapal tanker 17500 LTDW adalah dengan perhitungan melalui General Arranggement (GA) yang dibuat oleh PT PAL Indonesia. Berdasarkan data tersebut dilakukan perhitungan volume ruangan, jumlah penghuni ruangan, suhu dan kelembaban, peralatan listrik (equipment), jumlah lampu, jumlah jendela, jenis ruangan yang membutuhkan pendinginan berdasarkan kegunaan, dan posisi ruangan. Selanjutnya dapat dihitung entalpi, kapasitas udara, jumlah sirkulasi, \% fresh air, dan cooling capacity pada suatu ruangan.

\section{A. Waktu dan Tempat Penelitian}

Penelitian ini dilakukan selama 1,5 bulan mulai dari tanggal 2 Juni - 16 Agustus 2018, penelitian dilakukan di Gedung Divisi Desain, Departemen Machinary Outfitting, PT PAL Indonesia, Surabaya, Jawa Timur. 


\section{B. Objek dan Peralatan Penilitian}

Objek dan peralatan penelitian yang digunakan adalah :

1) Objek Penelitian

Dalam kasus ini yang dijadikan sebagai objek adalah Kapal Tanker 17500 LTDW buatan PT PAL Indonesia.

2) Pealatan Penelitian

Peralatan penelitian yang digunakan dalam proses perhitungan volume ruangan adalah Software CAD 2018 dan Excel yang disediakan PT PAL Indonesia.
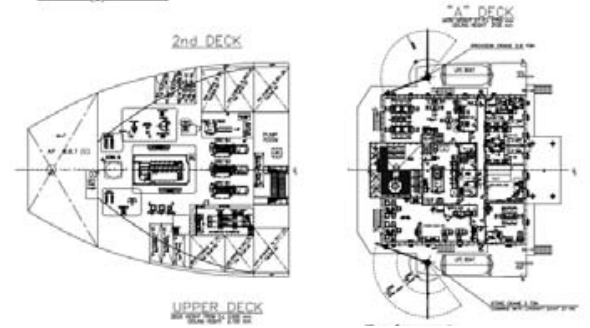

Gbr 1. General Arrangement Kapal Tanker 17500 LTDW (sumber: PT. PAL Indonesia (Persero)).

C. Prosedur Pengambilan Data

1) Persiapan Alat

Persiapan alat untuk pengambilan data dilakukan dengan menggunakan sebuah PC yang telah terinstal aplikasi CAD. Hal ini diperlukan karena untuk menghitung keseluruhan volume ruangan berdasarkan ukuran dimensi yang hanya bias dilakukan dengan Aplikasi CAD.

2) Tahapan Pengambilan Data

Perhitungan dimulai dari mengukur dimensi (panjang, lebar, dan tinggi) dan volume ruang Kapal Tanker 17500 LTDW pada deck sebagai berikut:

a) Upper Deck.

b) A Deck.

c) $\mathrm{B}$ deck.

d) C Deck.

e) Nav Bridge Deck.

Perhitungan parameter yang menentukan cooling capacity pada Kapal Tanker 17500 LTDW

Adapun detail dari kegiatan tersebut antara lain:

a) Menghitung jumlah orang dalam setiap ruangan berdasarkan kegunaan dan jumlah kursi yang tersedia.

b) Menentukan RH (Relative Humidity) Temperature Inside dan Outside, biasanya telah ditetapkan oleh maker (pembuat kapal).

c) Menghitung parameter Wall (F-A Wall, Side Wall, Floor).

d) Menentukan dan menghitung ruangan mana yang mempunyai jendela, jenis jendela (sun shine atau shadow), berapa jumlah jendela, dan berapa luas dari jendela tersebut.

e) Menentukan besar panas dari lampu yang digunakan dalam ruangan (Incandescent atau Fluorescent). Umumnya lampu yang digunakan untuk ruang akomodasi kapal adalah tipe Fluorescent.

f) Menentukan panas dari peralatan dalam ruangan, panas ini tergantung dari jenis dan kapasitas peralatan yang terpasang dalam ruangan tersebut.

g) Menghitung panas yang berasal dari penghuni, menurut ASHRAE 1964 Guide and Data Book Heat Gain from People (for Marine Air Conditioning Loads).

h) Menghitung Heat Calculation yang diperoleh dengan menjumlahkan parameter wall, window, light, equipment, dan person.

i) Menentukan sirkulasi udara (Air Change) di setiap ruangan.

j) Menghitung kapasitas udara dalam ruangan dengan menggunakan rumus: volume ruang $\mathrm{x}$ Air Change.

k) Menghitung nilai dari FA yang diperoleh dari konstanta $30 \mathrm{x}$ jumlah orang.

1) Menghitung nilai \%FA yang diperoleh dari FA / (Air Capacity x 100).

m) Perhitungan parameter Psychrometric Diagram dan Cooling Capacity pada kapal Tanker 17500 LTDW

\section{HASIL DAN PEMBAHASAN}

Untuk perhitungan kapasitas pendinginan kapal Tanker 17500 LTDW terbagi dari beberapa tahap antara lain :

\section{A. Heat Calculation}

1. Perhitungan Beban Panas Transmisi

Untuk perhitungan beban panas transmisi diambil contoh perhitungan pada Wheel house yang terletak di N.B. Deck.

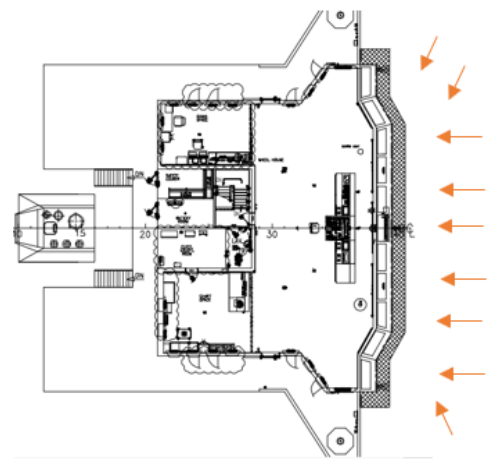

Gbr 2. General Arrangement Wheel House N.B Deck

Diketahui :

Nilai Koefisien transfer panas pada dinding untuk kapal Tanker 17500 LTDW pada tahap desain awal diasumsikan $=0.9 \mathrm{~W} / \mathrm{m}^{\mathrm{C}} \mathrm{i}_{\mathrm{p}}$

Inside temperature $\quad: 24^{\circ} \mathrm{C} ; \mathrm{RH}: 50 \%$

Outside temperature $\quad: 35^{\circ} \mathrm{C}$; $\mathrm{RH}: 70 \%$ 


$$
\begin{aligned}
\text { QTR F-A WALL } & =(\mathrm{k} \cdot \mathrm{A} . \Delta t) \times 2 \\
& =(0.9 \times(\mathrm{B} \times \mathrm{H}) \times 11) \times 2 \\
& =(0.9 \times(14.6 \times 2.1) \times 11) \times 2 \\
& =607.07 \text { watt } \\
\text { QTR SIDE WALL } & =(\mathrm{k} \cdot \mathrm{A} . \Delta t) \times 2 \\
& =(0.9 \times(\mathrm{H} \times \mathrm{L}) \times 11) \times 2 \\
& =(0.9 \times(2.1 \times 7.37) \times 11) \times 2 \\
& =306.53 \text { watt } \\
\text { QTR FLOOR } & =(\mathrm{k} . \mathrm{A} . \Delta t) \times 2 \\
& =(0.9 \times(\mathrm{L} \times \mathrm{B}) \times 11) \times 2 \\
& =(0.9 \times(7.37 \times 14.6) \times 11) \times 2 \\
& =2131.10 \text { watt }
\end{aligned}
$$

Maka :

$$
\begin{aligned}
\text { QTR total }= & \text { QTR F-A WALL + QTR SIDE } \\
& \text { WALL }+ \text { QTR FLOOR } \\
= & 607.07 \text { watt }+306.53 \text { watt }+ \\
& 2131.10 \text { watt } \\
= & 3044.69 \text { watt }
\end{aligned}
$$

2. Beban Panas Jendela

Untuk perhitungan beban panas pada jendela diambil contoh perhitungan pada Wheel house yang terletak di N.B. Deck.

Diketahui :

$$
\begin{array}{ll}
\text { Jendela tipe sunshine } \mathrm{K} & : 6.5 \mathrm{w} / \mathrm{m}^{2}{ }^{\circ} \mathrm{C} \\
\text { Jumlah jendela } & : 21 \mathrm{buah} \\
\text { Luas Jendela } & : 1,34 \mathrm{~m}^{2} \\
\Delta \mathrm{t} & : 11^{\circ} \mathrm{C}
\end{array}
$$

Maka :

$\mathrm{Q}=\mathrm{k} \cdot \mathrm{A} \cdot \Delta \mathrm{t}$

$=6.5 \mathrm{w} / \mathrm{m}^{2}{ }^{\circ} \mathrm{C} \cdot 1,34 \mathrm{~m}^{2} \cdot 11^{\circ} \mathrm{C}$

$=2012,01$ watt

Jadi untuk beban panas jendela pada ruang Wheel house yang terletak di N.B. Deck. yang berjumlah 21 buah : 2012,01watt

3. Beban Panas dari Lampu

Beban panas dari lampu ditentukan dengan cara melihat dari tabel II. Lighting heating load conversion, dimana juga ditentukan apakah lampu itu tipe Incandescent atau Fluorescent. Diambil contoh pada Wheel house yang terletak di N.B. Deck. Diketahui :

Nilai Koefisien panas dari lampu pada Wheel house yang adalah $20 \mathrm{~W} / \mathrm{m}^{2}{ }^{\circ} \mathrm{C}$

(tabel 2.6 Lighting heating load conversion ).

Luas dari ruang Wheel house: $107.63 \mathrm{~m}^{2}$ $\Delta \mathrm{t}: 11^{\circ} \mathrm{C}$

$$
\text { Maka, } \quad \begin{aligned}
\mathrm{Q} & =\mathrm{k} . \mathrm{A} . \Delta \mathrm{t} \\
& =20 \mathrm{~W} / \mathrm{m}^{2} \cdot 107.63 \mathrm{~m}^{2} .11^{\circ} \mathrm{C} \\
& =23678.8 \text { watt }
\end{aligned}
$$

4. Beban Panas dari Orang

Berdasarakan tabel I. Panas dari Penghuni sensible dan latent (Btu/hr).

Diketahui :

Heat Rate Wheel house $\quad:(101 \mathrm{Kcal} / \mathrm{h}=117$ Watt $)$
Jumlah penghuni $\quad: 1$ orang

Maka : $\mathrm{Q}=\mathrm{k}$.Quantity person

$$
\begin{aligned}
& =117 \text { watt } .1 \\
& =117 \text { watt }
\end{aligned}
$$

5. Beban Panas Peralatan

Jumlah panas yang disebabkan oleh peralatan dalam suatu ruang tergantung dari jenis dan kapasitas perlatan yang terpasang. Berdasarkan Tabel 3. 7 Beban Panas Peralatan.

Diketahui :

Beban panas peralatan pada Wheel house $(1000-2500)$ watt $=2000$ watt (asumsi)

Maka : Beban panas peralatan pada Wheel house yang didapat 2000 watt.

6. Beban Panas Total (Heat Calculation)

Maka jumlah beban panas total yang dialami pada ruang Wheel house adalah :

$\mathrm{QR}=$ Beban Panas Transmisi + Beban Panas Jendela + Beban Panas dari Lampu + Beban Panas

Penghuni + Beban Panas Peralatan.

$=3044.69+2012.01+23678.8+117+2000$

$=30852.57$ watt

B. Perhitungan Cooling Capacity

1. Penentuan Sirkulasi Udara

Untuk penentuan kapasitas udara dapat dilihat dari tabel III. Sirkulasi udara dalam ruangan. Sebagai contoh penentuan sirkulasi udara digunakan ruang Wheel house yang terletak di 01 level Deck.

Diketahui :

Wheel house $\quad: 12$ kali sirkulasi dalam 1 jam.

2. Penentuan Kapasitas Udara

Diambil contoh pada Wheel house yang terletak di N.B. Deck.

Diketahui :

Densitas Udara $\quad: 1,2 \mathrm{~kg} / \mathrm{m}^{3}$

Panas Spesifik Udara $: 1 \mathrm{KJ} / \mathrm{KG}^{\circ} \mathrm{C}$

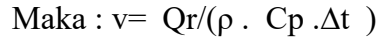

$$
\begin{aligned}
\mathrm{v} & =(5825,08 \mathrm{watt}) /\left(1,2 \mathrm{~kg} / \mathrm{m}^{3} .1 \mathrm{Kj} / \mathrm{Kg}^{\circ} \mathrm{C} .11^{\circ} \mathrm{C}\right) \\
& =2337.32 \mathrm{~m}^{3} / \mathrm{h}
\end{aligned}
$$

3. Perhitungan Parameter Udara Segar

Penentuan parameter Fresh Air ini digunakan untuk menentukan berapa banyak campuran udara yang dibutuhkan oleh Air Handling Unit. Adapun parameter Fresh Air ini dapat dihitung dengan cara :

Diketahui :

Contoh Wheel house yang terletak di N.B. Deck.

Nilai dari konstanta FA ditentukan sebesar 30\% dari total udara yang digunakan untuk suplai udara pada kondensor ( Fresh Air 30\% ; Return Air 70\% )

Maka: FA $=30$. Quantity Person

$=30.1$ orang

$=30 \mathrm{~m}^{3} / \mathrm{h}$

$\% \mathrm{FA}=\mathrm{FA} /($ Air Change. Volume $) \mathrm{x}$ $100 \%$

$=\left(30 \mathrm{~m}^{3} / \mathrm{h}\right) /\left(12 \mathrm{x} / \mathrm{h} \cdot 46,494 \mathrm{~m}^{3}\right)$

x $100 \%$

$=1.11 \%$ 
4. Perhitungan Enthalphy

Diambil contoh Wheel house yang terletak di N.B.

Deck.

Diketahui :

Nilai dari Heat Gain $80 \mathrm{~W} / \mathrm{p}$

Densitas udara : $1,2 \mathrm{~kg} / \mathrm{m}^{3}$

Jumlah penghuni pada Wheel house 1 orang

Air Change : $12 \mathrm{x} / \mathrm{h}$

Volume ruang : $226.02 \mathrm{~m}^{3}$

Maka : $\Delta$ he $=($ Qty person . Heat Gain $) /(\rho$. V. Air Change )

$\Delta$ he $=(1$ person $.80 \mathrm{~W} / \mathrm{p}) /\left(1,2 \mathrm{~kg} / \mathrm{m}^{3}\right.$. $\left.46,494 \mathrm{~m}^{3} .11 \mathrm{x} / \mathrm{h}\right)$

$$
=0.02 \mathrm{KJ} / \mathrm{Kg}
$$

5. Psychrometric Diagram

Untuk Perhitungan pada psikrometri diagram terdapat beberapa parameter antara lain :

1) Parameter $\mathrm{AB}$

Langkah-langkah menentukan parameter A-B adalah :

a) Tarik garis lurus dari D-A berdasarkan temperature inside (dalam kasus ini ditentukan $24^{\circ} \mathrm{C}$ ) hingga berpotongan dengan Garis RH (dalam kasus ini 50\%) yaitu pada titik A. (Garis Ungu)

b) Tarik garis lurus dari C-B berdasarkan temperature outside (dalam kasus ini ditentukan $35^{\circ} \mathrm{C}$ ) hingga berpotongan dengan Garis RH (dalam kasus ini 70\%) yaitu pada titik B. (Garis Merah)

c) Kemudian tarik garis A-B sehingga didapat garis sepanjang 37.24 in (Garis Hijau)

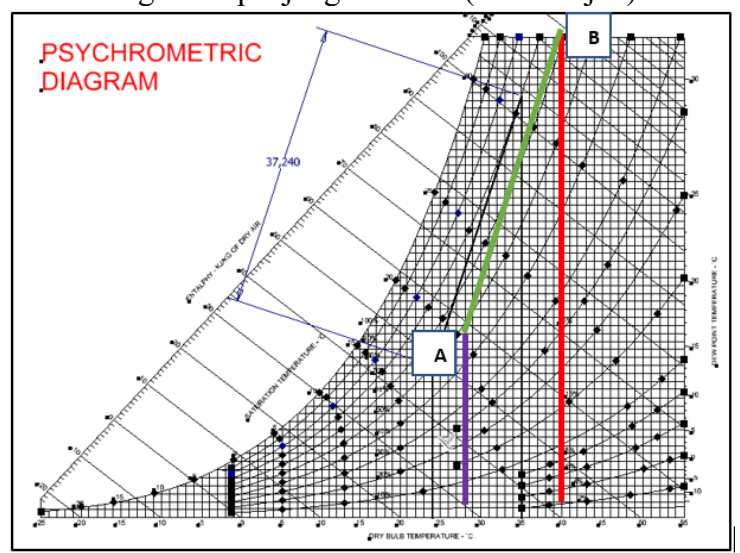

Gbr 3. Parameter AB Psychrometric Diagram

2) Parameter $\mathrm{AC}$

Parameter AC didapat dengan menggunakan formula :

$(\mathrm{AB} \times \% \mathrm{FA}) / 100$

Diambil contoh pada Wheel house yang terletak di N.B. Deck.

Diketahui :

Parameter AB : 37.24 ; \%FA : 8,07\%

Maka $\quad \mathrm{AC}=(37.24 \times 0.02) / 100$

$=0.41$
3) Perhitungan Parameter h1

a) Paremeter hl didapat dengan cara membuat garis yang berhimpitan dengan garis $\mathrm{AB}$ (garis hijau) sebesar nilai AC (3.00 in).

b) kemudian ditarik garis lurus sejajar dengan garis pada parameter Enthalphy of Dry Air. Nilai tersebut dinamakan Parameter h1. Dalam kasus ini didapat nilai h1 $=49$. (garis oranye).

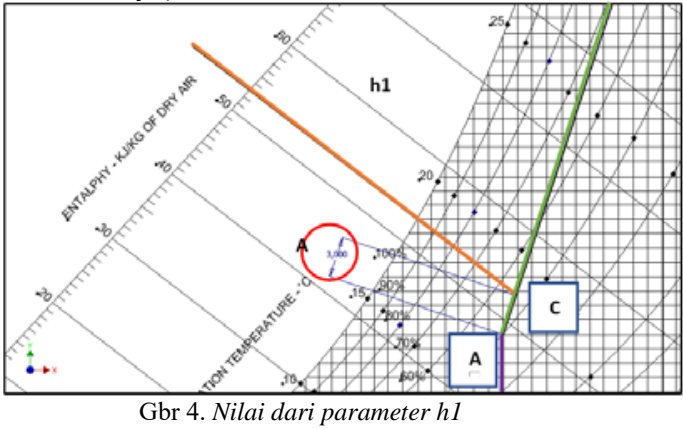

4) Perhitungan Parameter h2

a) Parameter h2 didapat dari menarik garis sejajar dengan garis h1 (garis Oranye) yang berasal dari titik (A), sehingga jadilah titik (E) (garis biru muda).

b) Kemudian kurangi nilai yang di dapat oleh (E) dengan Enthalphy sebesar nilai dari $\Delta$ he, sehingga didapat nilai $(\mathrm{F})$.

c) Dari titik (F) kemudian ditarik garis sejajar dengan garis biru muda hingga berpotongan dengan garis temperatur inside sehingga muncul titik $(\mathrm{G})$ (garis merah muda).

d) Kemudian dari titik $(G)$ tarik garis horizontal hingga berpotongan dengan garis $\mathrm{RH}$ sebesar 95\% titik $(\mathrm{H})$.

e) Kemudian dari titik $(\mathrm{H})$ buat garis sejajar dengan garis merah muda menuju pada garis enthalphy. Nilai yang ditunjukkan pada garis Enthalphy merupakan nilai dari parameter h2.

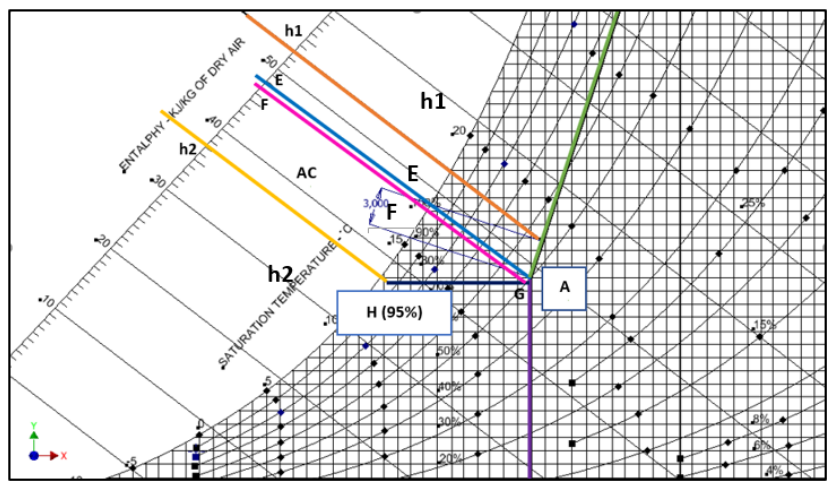

Gbr 5. Nilai dari parameter h2 
5) Parameter $\Delta k$

Parameter $\Delta \mathrm{h}$ diperoleh dari formula berikut : $\Delta \mathrm{h}=\mathrm{h} 1-\mathrm{h} 2$

Diambil contoh Wheel house yang terletak di N.B. Deck.

Diketahui :

$$
\begin{aligned}
& \mathrm{h} 1=49 \\
& \mathrm{~h} 2=37.95
\end{aligned}
$$

Maka, $\Delta \mathrm{h}=\mathrm{h} 1-\mathrm{h} 2$

$$
\begin{aligned}
& =49-37,66 \\
& =11.05 \mathrm{KJ} / \mathrm{Kg}
\end{aligned}
$$

6. Perhitungan Kapasitas Pendinginan (Cooling Capacity) Diambil contoh pada Wheel house yang terletak di N.B. Deck.

Diketahui :

Densitas udara $=1,2 \mathrm{~kg} / \mathrm{m}^{3}$

$\Delta \mathrm{h} \quad=11.05 \mathrm{KJ} / \mathrm{Kg}$

Kapaitas udara yang akan disuplai

$$
(\mathrm{v})=\mathrm{V} \text {. Air change }
$$

$$
\begin{aligned}
& \text { Maka : } \\
& \begin{aligned}
\text { QC } & =\mathrm{v} . \rho . \Delta \mathrm{h} \\
& =226.02 \mathrm{~m}^{3} .1,2 \mathrm{~kg} / \mathrm{m}^{3} .11 .05 \mathrm{KJ} / \mathrm{Kg} \\
& =35.960 \text { watt }(35.96 \text { Kilowatt })
\end{aligned}
\end{aligned}
$$

\section{KESIMPULAN}

Berdasarkan dari tujuan khusus dan pembahasan diatas, maka dapat diambil kesimpulan sebagai berikut:.

1. Total kapasitas pendingin (Cooling Capacity) yang dibutuhkan oleh kompresor pada ruang akomodasi Kapal Tanker 17500 LTDW ditemukan sebesar 487,87 KW. Adapun dengan rincian data sebagai berikut:

a. Kapal dirancang dalam Summer Condition (iklim tropis) sesuai permintaan customer dengan :
1) inside condition : temperature $=24^{\circ} \mathrm{C}$

$$
\text { Relative humidity }=50 \%
$$

2) outside condition:temperature $=35^{\circ} \mathrm{C}$. Relative humidity $=70 \%$

b. Jumlah Beban Panas Transmisi $=36127.82$ Watt.

c. Jumlah Beban Panas Jendela $=3449.88$ Watt.

d. Jumlah Beban Panas Lampu $=148037.79$ Watt.

e. Jumlah Beban Panas Penghuni $=12182$ Watt.

f. Jumlah Beban Panas Peralatan $=11000$ Watt.

g. Jumlah Beban Panas Total $=210797.48$ Watt.

h. Jumlah Air Capacity yang dibutuhkan $=21252.42$ $\mathrm{m}^{3} / \mathrm{h}$.

\section{REFERENSI}

[1] ASHRAE Handbook, 1997. Fundamental SI Edition.

[2] ASHRAE Handbook,2001. Fundamental SI Edition.

[3] Burdick, A. (2011). Strategy Guideline: Accurate Heating and Cooling Load Calculations, (June). https://doi.org/10.2172/1018100

[4] Husodo, B. Y., \& Br. Siagian, N. A. (2014). Analisa audit konsumsi energi sistem, 5(1), 49-58.

[5] Jaya, Dardiri. (2017). "Laporan On The Job Training Di PT. PAL Indonesia (Persero)". Laporan Praktik Industri PT. PAL Indonesia (Persero).

[6] Moran, M. J., \& Shapiro, H. N. (1998). Fundamentals of engineering thermodynamics: SI version. Chichester: John Wiley.

[7] PT. PAL Indonesia. 2000. Basic Design (HOD). Surabaya: PT. PAL Indonesia (Persero).

[8] Sumaryanto. (2013). Konsep Dasar Kapal, 1-136.

[9] Utomo, B. (2007). Sistem Ventilasi dalam Kapal. Teknik, 28(1), 76-82.

[10] Widhikdho, Ade (2017). "Laporan Praktik Industri Proses Pembuatan Bucket Cat 320-D di PT. Sarana Mitra Sejati”. Laporan Praktik Industri PT. Sarana Mitra Sejati. 